\title{
Remaking the World of Chinese Labour: A 30-Year Retrospective
}

\author{
Eli Friedman \\ University of California \\ Ching Kwan Lee \\ University of California
}

\begin{abstract}
Over the past 30 years, labour relations, and, indeed, the entirety of working class politics in China, have been dramatically altered by economic reforms. In this review, we focus on the two key processes of commodification and casualization and their implications for workers. On the one hand, these processes have resulted in the destruction of the old social contract and the emergence of marketized employment relations. This has implied a loss of the job security and generous benefits enjoyed by workers in the planned economy. On the other hand, commodification and casualization have produced significant but localized resistance from the Chinese working class. Up until now, the activities of labour nongovernmental organizations and of the official trade unions have contributed to the state's effort of individualizing and institutionalizing labour conflict resolution through labour law and arbitration mechanisms. Finally, we provide a brief discussion of the impact of 2008's Labour Contract Law and the outbreak of the economic crisis on labour relations. We conclude that the continual imbalance of power at the point of production presents a real dilemma for the Chinese state as it attempts to shift away from a model of development dependent on exports.
\end{abstract}

\section{Introduction}

Two historical processes have fundamentally transformed the worlds of Chinese employment in the past three decades: commodification and casualization. Both tendencies, driven by economic and political forces within and beyond China, have spawned a precipitous decline in labour standards and a palpable rise in labour discontent and unrest that is cellularized, localized and uncoordinated. Adhering to a model of economic development dependent on high rates of exploitation, the Chinese leadership has sponsored a historic overhaul of the socialist employment system since the 1980s, disempowering the working class at the point of production while ordaining a panoply of 'rights' in the legal and 
administrative systems. If Chinese labour under Mao was a state-controlled and organized class, in the reform period, a formidable alliance of interest between the Chinese state and capital, both global and domestic, has rendered it disorganized and individualized, capable of occasional sparkles of rebellion but without sustainable collective power.

The story of Chinese labour is hardly unique. Around the world, examples abound about the erosion of the social contract, multiple forms of 'flexible' employment and dispossession of worker entitlements. Yet the enormity of the Chinese workforce-the largest in the world at more than 800 million - and centrality of China in the global economy, gives particular poignancy to the condition of Chinese labour. In this overview of Chinese labour in the post-Mao era, we wish to highlight the characteristics of the Chinese political economy and the social composition of the labour force that shape the peculiar processes and politics of commodification, casualization and cellularization. In what follows, we will first depict the shifting nature and structure of employment, evolving from the socialist social contract to the market-driven, legal contract (or no contract) for labour. The second part of the article contextualizes these shifts in employment in the configuration of state and capital interests and power relations, as well as policies of migration that have led to the formation of the new working class consisting mostly of migrant labourers. This discussion of the political economy of employment will be followed by a three-way analysis of the 'contested terrain' of Chinese labour. We will see that legal reform is a strategy of the state to regulate and contain labour resistance, while workers pursue both legal and extra-legal means of activism, and unions and labour non-governmental organizations (NGOs) develop as a force of political stabilization alongside an increasingly restive work force. We conclude by examining some significant recent events in China's labour politics, namely the enactment of the Labour Contract Law and the onset of the financial crisis, both occurring in 2008. They show that while labour does not necessarily present a political challenge to the state in the short to mid term, it does present constraints on the state's attempt to switch models of accumulation from one dependent on exports to one based on domestic consumption.

\section{Employment reform: from social contract to legal (or no) contract}

\section{Commodification of Labour}

The commodification of labour has been the constitutive process of China's turn to capitalism. Like other kinds of commodities, the human capacity to transform nature can now be alienated from one person and sold to others. This process has been tumultuous and painful for Chinese workers, not the least because the Chinese employment system put in place under the state socialist period, from the 
1950 s to the late 1980 s, was a de-commodified one. Vividly captured by the famous Chinese expression the 'iron rice bowl', it was a system in which urban workers were administratively allocated to a de facto job tenure system in urban work units that formed a hierarchy of their own, with state owned enterprises at the apex, followed by collective enterprises run by various levels of the government. Workers formed a socio-political status group whose lifestyle and life chances (i.e. cradle to grave welfare, entitlements to pensions, housing, medical care and educational opportunity) were guaranteed and enforced by the state to whom workers would pledge political loyalty and compliance. Hence, the notion of the 'socialist social contract'. During this period, there were a minority of casual workers recruited from the countryside into state owned enterprises during production campaigns. But by and large, the Chinese workplace was characterized by lifetime employment with minimal mobility, while also serving as the most basic unit of political control organized by the Chinese Communist Party (Walder 1986).

The socialist system of employment was overhauled along with the restructuring of the Chinese economy away from central planning and state ownership, towards one driven by market competition and multiple ownership forms. With the rise of the private and foreign economic sectors not bounded or burdened by the iron rice bowl employment system, state enterprises were compelled to break the iron rice bowl policy to stay competitive. Over a protracted period of about 20 years, the Chinese government attempted to institutionalize a labour rule of law, or to regulate employment relations through a series of labour legislations, all founded on the notion of the market-oriented, voluntaristic and individualistic 'labour contract'. Not only did workers lose their right to employment, but reform of the pension, housing and medical systems throughout the 1980s and 1990s have also drastically curtailed workers' rights to welfare entitlements. Most of these benefits are now delivered on the basis of employer and employee contributions to insurance plans, responsibilities that by law should be stipulated in the labour contract (Lee 2007: ch. 1).

The shift from socialist social contract to legal labour contract has proven a Herculean task, because enforcement of the National Labour Law, the touchstone of the new employment system in the reform period, has come up against different kinds of resistance. The National Labour Law took effect in 1995 , and formally requires that all employees in all types of enterprises sign labour contracts with their employers. However, from the beginning, compliance has been spotty, especially so in the private and foreign sectors, which have outgrown the state sector in terms of employment and account for just 
above 50 per cent of all urban employment today (see Figure 1). In a 2007 report to the National People's Congress, China's legislative body, an official responsible for labour legislation stated that only about 50 per cent of all enterprises have signed contracts with their employees, and the rate among non-state firms was only 20 per cent. Among the labour contracts that were signed, $60-70$ per cent were short-term contracts of under one year (Eastern Center for Legal Culture 2008: 5). The State Council's 2006 Research Report on China's Migrant Workers provides an authoritative portrait of precarious labour in which labour rule of law is conspicuously absent. According to a 40-city survey conducted by the Labour and Social Security Ministry in 2004, among the 120 million strong migrant labour force from the countryside, a paltry 12.5 per cent has signed a labour contract, while only 15 per cent participate in social security scheme, and 10 per cent has medical insurance (State Council Research Office Team 2006: 13). Less than half (48 per cent) of the migrant workforce get paid regularly, while 52 per cent reported regular or occasional wage non-payment (State Council Research Office Team 2006: 116).

FIGURE 1

Urban Employment by Ownership Type.

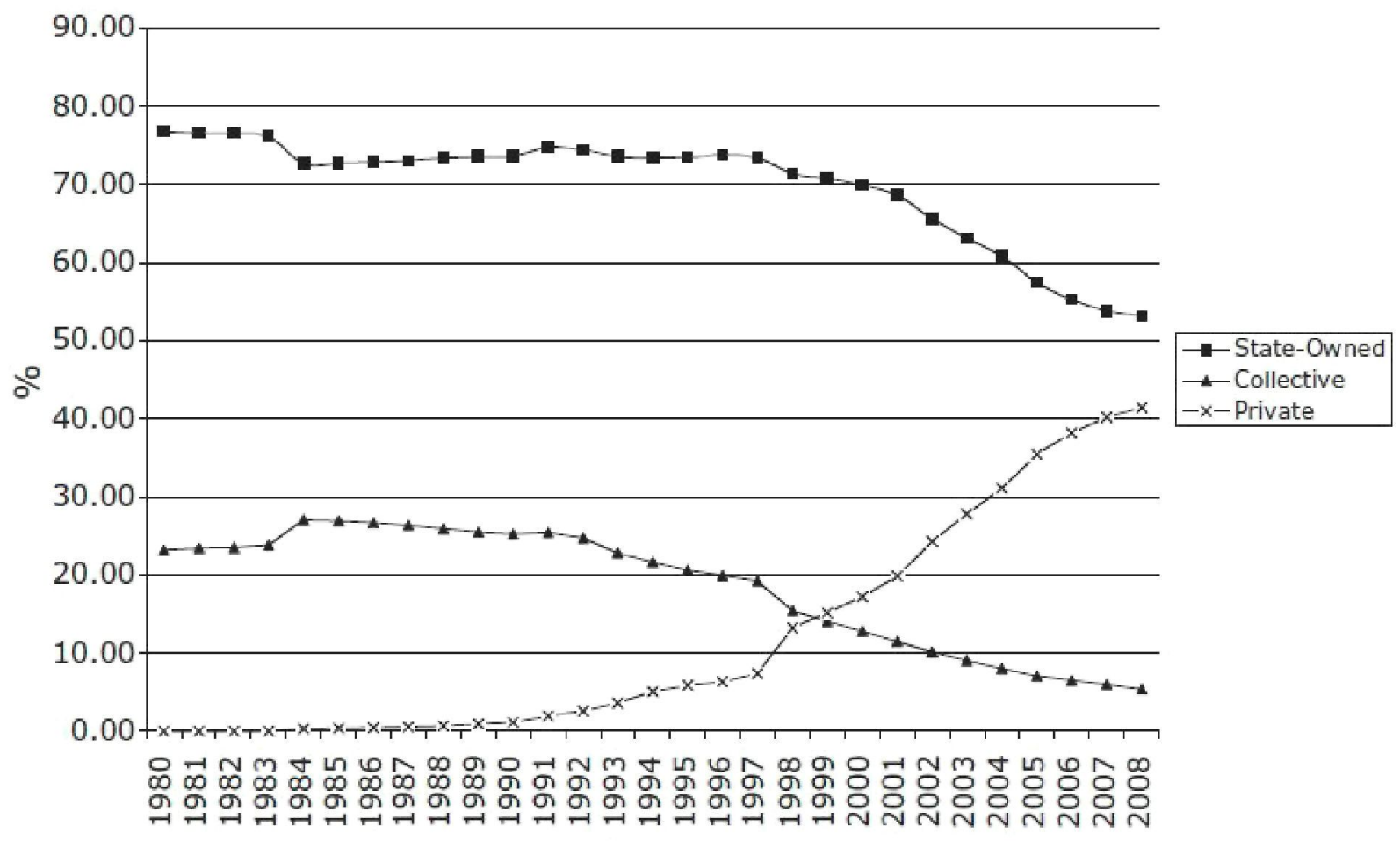

Year

Source: China Statistical Yearbook, 2009. Beijing: Zhongguo tongji chubanshe. 
Sixty-eight per cent of migrant workers work without any weekly day of rest, 54 per cent of migrant workers have never been paid overtime wages as required by law and 76 per cent do not receive the legal holiday overtime wages (State Council Research Office Team 2006: 214). These are only some of the most egregious violations of the National Labour Law, a decade after its promulgation.

\section{Casualization of Employment}

Running in tandem with the general trend of privatization in the state-owned sector and an evisceration of the social contract, employment in China has become greatly informalized across nearly all sectors. Two economists have mined various sources of statistics and found 'an unprecedented rise in informal employment in urban China since the mid-1990s. By 2005, 10 per cent of urban workers were registered as self-employed and another 36 per cent were undocumented, neither reported by employers or self-registered'

FIGURE 2

Type of Employment $1980-2008$.

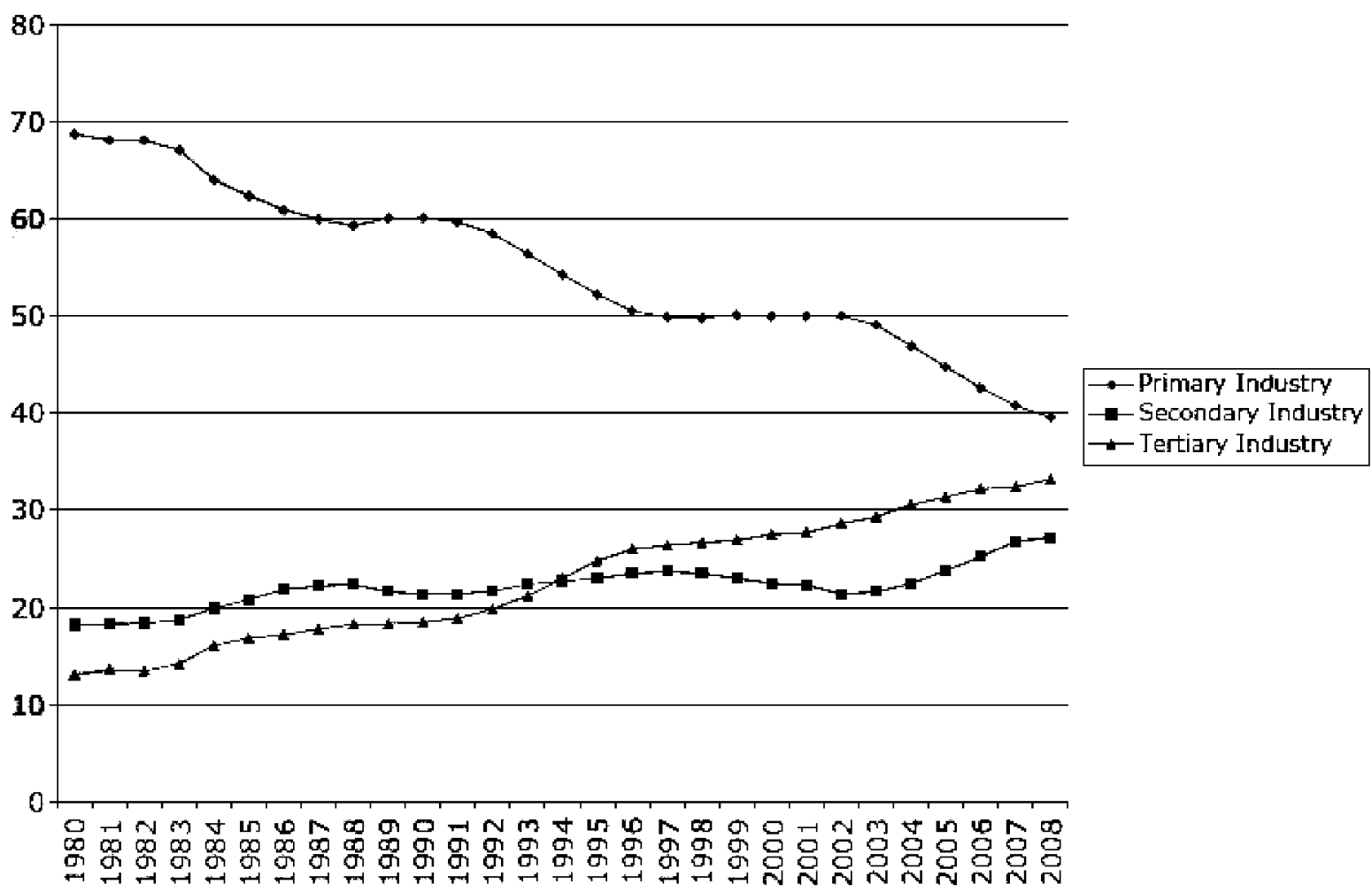

Year

Sources: China Statistical Yearbook, 1991, 1994, 2009. Beijing: Zhongguo tong/i chibanshe. 
(Park and Cai 2007). The increasingly informal nature of employment can be seen through an analysis of two dominant trends within China: (i) the re-organization of employment away from manufacturing; and (ii) the increasing prevalence of temporary and 'dispatch' workers in all sectors of the economy, including the state-owned manufacturing sector and in heavy industry.

As argued convincingly by Evans and Staveteig (2009), China's model of development is markedly distinct from the classic English one in the sense that a relatively small percentage of the country has been employed in the manufacturing sector. The percentage of Chinese workers employed in manufacturing peaked in the mid-late 1990s and began to gradually decline. Although it picked up again after WTO entry in 2001, it has been obviously outpaced by growth in tertiary industries (see Figure 2). What is more, the contribution of tertiary industries to economic growth has been increasing quite rapidly, with its share of GDP rising to 47.4 per cent in the first half of 2009 (People's Daily Online, 27 July 2009). As China begins to move up the value chain and increasingly focuses on capital, rather than labour, intensive industries, it is unlikely that surplus agricultural labour will continue to be absorbed by manufacturing. The collapse of the export economy in late 2008 has compounded the problem. With the percentage of workers employed in tertiary industries increasing from 19.8 per cent in 1992 to 33.2 per cent in 2008 (Zhongguo tongji zhaiyao 2009: 44), most of the recent gains in employment have come in the service sector. Without a doubt, a significant portion of these jobs are white collar office jobs, which tend to come with at least somewhat higher pay, better benefits, and closer adherence to relevant labour laws. But the bulk of new service sector employment is in industries such as food and beverage, hotels, entertainment, cleaning, healthcare, etc. Workers in such industries are highly subject to the vagaries of the market, as well as personal recriminations from employers. Although union presence is not necessarily an indicator of greater stability in employment, unions subordinate to the All China Federation of Trade Unions (ACFTU) have, until quite recently, overlooked the service sector. In general, legal enforcement and state supervision is weak to non-existent, and a huge number of workers are still employed without a contract, thereby leaving them more subject to summary wage deductions, firings, etc. Without a collective or institutional mechanism for enforcing labour laws, employment in the service sector has been, and continues to be, highly informal. Since more and more Chinese workers are employed in this sector, the implication is that more and more jobs are informal ones.

But even in the comparatively formalized manufacturing sector, the unmistakable trend has been towards increased flexibilization of employment relations. Referred to in China as 'dispatch workers,' these individuals are employed by hiring companies which then 'dispatch' them to 
manufacturers in need of a highly flexible, and highly exploitable, workforce. Estimated to number about 270 million in 2008 (Qiao 2009: 322), dispatch workers are only supposed to be employed at temporary, auxiliary or substitute positions, and they are to be remunerated according to the principle of 'equal pay for equal work', according to the 2008 Labour Contract Law (Y. Liu 2009). Although the emergence of dispatch workers is a relatively recent occurrence, there have already been many indications that managers (who are not the employers) use their ambiguous formal position vis-à-vis workers in order to routinely violate existing labour laws (Coke Concerned Student Group 2009), something which the government has so far done little to correct (Sun 2009). By obfuscating the relationship between manager, worker and employer, the dispatch labour system leaves workers in an incredibly precarious position in which they enjoy almost no job security whatsoever.

This method of employment has not been relegated to small enterprises in labour intensive industries as one might expect, but rather has penetrated even highly rationalized, highly mechanized, capital intensive industries in which workers used to enjoy a high level of security and relative material prosperity. In state-owned enterprises, previously the domain of the iron rice bowl, flexible, tiered employment systems have become increasingly popular among managers (Gallagher 2004, 2005; O. Zhang 2009), with dispatch workers appearing even in key industries, such as petrochemicals, railways, and telecommunications (Li 2005). Among centrally controlled state-owned enterprises, about 10 per cent of employees are dispatch workers (Qiao 2009: 322). Sectors such as the auto industry (L. Zhang 2008) and elevator manufacturers, 1 both of which require a relatively skilled workforce, employ regular contract workers alongside dispatch, temporary or 'intern' workers who necessarily receive markedly lower wages, benefits and job security. The effect of such a tiered employment system is that, in addition to subjecting the informal workers to poor treatment, solidarity and cohesion among the workforce is broken (L. Zhang 2008). Thus, such an arrangement is problematic not just from the perspective of the informal workers, but also from the regular workers, who will find it increasingly difficult to make collective demands on their employers.

\section{Labour Conditions and Rights Violations}

When commodified and casualized labour in a market economy is not effectively regulated by law, labour standards inevitably plummet and workers' plight is exacerbated. Notwithstanding the huge variation in working conditions based on sector, type of ownership, region and workforce composition, 
several common labour violations have plagued the Chinese workplace. While the government's occasional efforts to address such problems are welcome, labour rights violations are still endemic. This is in large part due to the fact that local governments - supposedly responsible for the implementation of national labour laws - are frequently much more concerned with capital accumulation than with law enforcement, a state of affairs that is tolerated by the central government. Thus, labour and legal rights violations cannot be attributed to the activity of a few 'bad apples', but rather are a fundamental feature of the model of development that the Chinese state has pursued over the past 30 years. The political economy of China's employment system will be discussed in the next section. Here, we want to spotlight some endemic problems that have arisen as a result of commodification and casualization.

The most common problems faced by Chinese workers include long hours, low pay, employer failure to pay overtime and social insurance, wage arrears, lack of proper health and safety precautions, discrimination (ethnic, gender, etc.), illegal firings, and severe fines for common workplace errors (A. Chan 2001). Among these, the following specific types of rights violations have received quite a lot of attention from researchers, the media and the government: (i) non-payment of wages and wage arrears. As one small indication of the severity of the problem, the ACFTU discovered in a partial survey of enterprises that have established a union that RMB 41.7 billion (USD\$6.1 billion) in wages were in arrears in 2003 (Zhong xin wang, 7 November 2004). This is surely but a small portion of the total sum. While this phenomenon is widespread in many industries in both the industrial and service sector, it has been particularly pronounced in construction. This is in large part because of the convoluted nature of the systems of financing and employment within the industry. (ii) Unpaid overtime wages: While regulations for payment of overtime have been widely publicized in recent years, employers frequently employ non-transparent methods of wage calculations, resulting in massive theft of overtime wages. (iii) Deaths in the coal industry: China's transition to a market economy, and the increased importance of non-state owned mines in coal production have lead to an increase in accidents (Wright 2004). As a result, around 6,000 miners a year were killed annually in the first several years of the decade (Liu et al. 2005: 510). (iv) Long/uneven hours: Particularly prominent in the highly seasonal consumer goods industries, it is not at all unusual for employers to demand that employees work for 12 or more hours a day, oftentimes without enjoying even a single day off per month.

These problems have not gone unnoticed by the government, and certain agents of the state, namely the trade union and the labour department, have taken steps to try to resolve the most egregious violations. Perhaps of greatest note is the 2008 Labour Contract Law (discussed in greater detail below), which has been an attempt to assert greater adherence to the law in labour relations. This 
law greatly increased possible fines on employers for refusing to sign contracts with employees, and there have been numerous reports that this has been relatively effective. More specifically, the government has recently undertaken an ambitious restructuring of the coal industry, in part to try to reduce the huge volume of deaths each year. According to official figures, there have been significant reductions in mining deaths as 2,632 workers were killed in 2009, an 18 per cent year on year reduction (The Guardian, 20 January 2010). Additionally, unions and labour departments in large cities have made efforts to deal with the problem of non-payment of wages. According to the national Ministry of Human Resources and Social Security, labour departments around the country recovered RMB 8.33 billion in back wages in 2008 .

All of these measures are welcome, and likely have helped to blunt the most brutal forms of exploitation that occurred in years past. And yet, the majority of actions taken by the state are attempts to address labour conflicts after the fact and through legal channels. Of greatest significance is the Labour Contract Law, which has gained the most attention among Chinese workers and employers. The hope is that all workers will hold a contract because the labour department is unable to process conflicts in the absence of such a document. However, the source of conflicts, that is lack of countervailing power at the point of production, has not been addressed by any of these steps. The government's legal actions are merely succour, and unlikely to resolve the fundamental power imbalance that is at the heart of poor working conditions.

\section{The political economy of Chinese employment}

The predicament of Chinese labour has roots in the authoritarian Chinese polity in which power is monopolized by the Chinese Communist Party, and workers are deprived of their most critical weapon: formation of workers' autonomous associations. This structural problem is compounded by the strategies of development pursued by the reform leadership. While these strategies have changed courses and emphases over the years and do not form a coherent or well-planned 'Chinese model', three central features are particularly relevant to understanding the rampant violations of labour standards. They are: local accumulation, rule by law and permanent migration.

First, local accumulation refers to the strategy of economic decentralization to enhance incentives among local elite to liberalize the economy. By allowing revenue retention at the provincial and local levels, fiscal decentralization has generated enormous vested interests among local officials to 
nurture a pro-capital climate favourable to investors, to privatize previously collectively owned or state owned enterprises, and to allow a weak regulatory regime of labour. The central government benefits from the increased taxation and revenue remission from the localities created by local accumulation, and has over time fought with the provinces to secure a larger share of the profits, as was evident in the fiscal reform of recentralization in 1994. By and large, both the central and local governments preside over the commodification and casualization of employment, and share a labour-squeezing strategy of development.

But the imperative of accumulation has to be balanced with one of legitimation, or the creation of consent among the subordinated classes, and of some means of conflict resolution so that stability can be maintained for accumulation to proceed on a peaceful and expanded basis. More fundamentally, the enforcement of labour contract requires the promulgation of the National Labour Law and institutionalization of a bureaucratic apparatus of regulating labour relations. This brings us to the strategy of 'rule by law', that is the attempt to channel conflicts into the bureaucratic and judicial apparatus controlled by the Chinese state. Unfolding concomitantly with economic reform in the past 30 years, Chinese legal reform entails a remarkable and momentous increase in law-making activities by the central authority and the professionalization of the judiciary and the legal workforce. 'Ruling the country by law' was written into the Constitution in 1999, and has become part of the lexicon widely adopted in government, legislature and Party reports, often mentioned as a means of maintaining social stability. Among the more than 400 laws enacted by the National People's Congress since 1979 are major labour legislations, including the National Labour Law (1994), the revised Trade Union Law (1992 and 2002), the Labour Contract Law (2007), the Employment Promotion Law (2007), and the Labour Dispute Mediation and Arbitration Law (2007). In addition, a large number of State Council edicts and ministry regulations (with various shades of formal legality) stipulate everything from minimum wage levels, workplace injury compensation, to medical coverage and pension rules. The problem has always been one of enforcement. With the Chinese judiciary dependent on local governments for financing and personnel appointment, and with local officials prioritizing accumulation, the courts are under enormous pressure to respond to political contingency in meting out decisions. Yet the existence of the law and the legal apparatus appear to workers as the only legitimate way of defending their interest. We shall discuss how workers' resistance is partly absorbed into this legal and bureaucratic maze and partly pushed to the street by the unpredictable and authoritarian system of 'rule by law'. 
Finally, the peculiar nature of the Chinese migration system is fundamental to the supply of lowwage migrant labour, as well as in preventing labour unrest from leading to radicalization and escalation. According to a national survey conducted by the All China Federation of Trade Unions in 2007, the migrant workforce is estimated to be 120 million strong, and accounts for 64.4 per cent of all workers in industrial employment and 33 per cent of employees in the service sector. Their average age is 32, and the average level of education is 10.4 years of formal schooling (Qiao 2009: 315). The vast majority of these migrant workers holds a rural household registration status, and has to apply for temporary residence permits in order to live and work in the urban areas. Many local pension regulations, medical policies and employment practices discriminate against them because they are not legally 'local' residents. This two-tier citizenship hierarchy has been put in place since the late 1950s, enforced by a locality-based ration system. It has functioned as a means of state control over the physical and social mobility of the population, and has guaranteed the transfer of rural surplus to urban industrialization. The system has been gradually loosened up since the 1980 s to provide an enormous labour pool for domestic and foreign capital, and has made possible China's export-oriented, labour intensive industrialization strategy. The cornerstone of this Chinese system of migrant labour is the collective land ownership arrangement in the villages where these workers originate. By law, every rural resident is entitled to a plot of land in her native village, owned and allocated by the village collective to which she is a member by birth. To date, despite the increase in land seizure in rural areas close to urban development centres, migrant workers maintain long-term social and economic ties to the family farmland, especially in times of unemployment, marriage and giving birth. As long as the migration regime and household registration system keep migrants' entitlement to education and medical care in the city inferior or inadequate, and the rural economy largely impoverished, Chinese migrant workers are locked in the position of being permanent migrants. Without the legal right to become urban citizens, migrants are reliant on jobs in the city to support family livelihood and social reproduction in the countryside. Empirical research has found that the safety valve of rural land ownership also inhibits the development of collective capacity, as many return to the countryside during times of crisis, unable or unwilling to sustain the long process of legal battles or extra-legal protests (Lee 2007). Their weak associational (no independent union) and workplace (mostly doing low-skilled work) leverage therefore is further stymied by the lack of sustained collective mobilization. As we shall examine in the next section, the forms of labour activism that have emerged under China's reform political economy, characterized by 'decentralized legal authoritarianism' discussed above, include legal and extra-legal mobilization, trade union legal representation and the rise of service-oriented labour NGOs. 


\section{Contested terrains}

Legal Mobilization

As a consequence of the government's promotion of 'rule by law', the promulgation of labour legislations, and the reform of the labour dispute resolution system, there has been a massive increase in formally processed labour disputes (see Table 1). Filing for labour dispute arbitration is the prerequisite for filing civil lawsuits. Beneath this aggregate rise in the volume of arbitrated disputes, certain patterns can be discerned, illustrating the focus and distribution of labour conflicts. First, the most contentious provinces in the 1990s have been Guangdong, Chongqing, Shanghai, Fujian and Jiangsu, regions that experienced the most rapid economic growth. Shenzhen, with its huge contingent of migrant workers numbering more than 6 million by 2000, alone accounted for one-tenth of the national total of arbitrated labour disputes by 1999. On the other hand, in terms of increase in arbitration, Sichuan, Inner Mongolia, Tianjin, Gansu, Shanxi and Xinjiang all registered triple digit rates in 1995, reflecting perhaps the rapid deterioration in employment conditions among workers in the stateowned sector. Secondly, in terms of ownership type, and taking the year 1996 as an example, stateowned enterprises account for 34 per cent of arbitrated disputes, while foreign invested, collective and private enterprises, respectively, account for 21,26 and 10 per cent of the total of 48,121 cases, involving 189,120 employees. Third, most disputes are economic in nature, with wages, welfare and social insurance payment being the most common (50 per cent) causes of conflicts, and another 30 per cent or so about contract termination and dismissal. Wage arrears are particularly pronounced in private and foreign-invested firms2 (those that are owned or partially owned by foreign capital). Most of these dispute cases originated in petitions by employees rather than employers. They succeeded in redressing grievances in 50-80 per cent of cases depending on the locality. However, the protection of workers' rights is still wanting, as implementing arbitral awards is not always guaranteed, and the labour dispute arbitration committees easily yield to pressure by local government and employers. Notwithstanding these shortcomings, both the government and the working public have taken this institution seriously and a new Labour Mediation and Arbitration Law was passed in 2007 to streamline the process of arbitration, eliminate arbitration fees and extend the time limit for aggrieved workers to file for dispute arbitration. In the first three quarters of 2008, China's labour dispute arbitration committees accepted 520,000 new cases, a 50 per cent increase over the same period in 2007 . The figure is expected to increase sharply in the following years, reflecting the rise in the number of factory closures and mass layoffs in the southeast coastal 
TABLE 1

National Total of Arbitrated Labour Disputes 1994-2007

\begin{tabular}{cccc}
\hline Year & $\begin{array}{c}\text { Arbitrated labour } \\
\text { dispute (cases) }\end{array}$ & $\begin{array}{c}\text { Arbitrated collective } \\
\text { dispute (cases) }\end{array}$ & $\begin{array}{c}\text { Employees } \\
\text { involved }\end{array}$ \\
\hline 1994 & 19,098 & 1,482 & 77,794 \\
1995 & 33,030 & 2,588 & 122,512 \\
1996 & 47,951 & 3,150 & 189,120 \\
1997 & 71,524 & 4,109 & 221,115 \\
1998 & 93,649 & 6,767 & 358,531 \\
1999 & 120,191 & 9,043 & 473,957 \\
2000 & 135,206 & 8,247 & 422,617 \\
2001 & 154,621 & 9,847 & 467,150 \\
2002 & 184,116 & 11,024 & 608,396 \\
2003 & 226,391 & 10,823 & 801,042 \\
2005 & 314,000 & 19,000 & 740,000 \\
2006 & 447,000 & 14,000 & 680,000 \\
2007 & 500,000 & 13,000 & 650,000 \\
\hline
\end{tabular}

Note: The first column indicates the totals for both individual and collective disputes. Collective disputes are cases involving five or more workers.

Source: Labour and Social Security Statistical Yearbooks, various years (2005-2006 are from summary statistics released by the Ministry of Labour and Social Security).

region.3 Also, the boundary between institutional and non-institutional, legal and extra-legal activism can be elusive. When workers are encouraged to seek legal and bureaucratic redress, only to find that the local state often colludes with employers, they are emboldened to resort to collective action to draw the attention of superior levels of government to right local wrongs.

\section{Worker Protests}

Though labour unrest was certainly not unheard of during the Maoist period (Lee 2010), the acceleration of privatization, restructuring and redundancies in the state-owned sector triggered levels of insurgency unknown in the history of the People's Republic. While protests occurred throughout the country, they were particularly severe in the country's industrial heartland of the Northeast (Hurst 2009). Suddenly subject to layoffs, increased precariousness, reduced wages and benefits, and 'subsistence crises' (Chen 2000), workers in the state-owned sector began actively and explicitly drawing on the concepts and ideology of Maoism in defence of their suddenly impingedupon livelihoods (Lee 2000,2002 ). The volume of such protest expanded through the late 1990s and early 2000s, and was symbolically capped by the spectacular protests in Liaoyang in the spring of 2002. While worker protest 
may have had the effect of slowing down the process of privatization and convincing the state to hold on to a significant number of large enterprises (Cai 2002), none of these episodes have been effective in arresting the processes of commodification and casualization.

Far-removed socially, and often time spatially, from the protests in the state sector, is the insurgency among China's 'new' working class of migrants from the countryside. Although these workers are younger, less educated, and more frequently female than their counterparts in the state-owned sector, over the past 10 years, they have defied stereotypes of docility and passivity and have been engaging in all manner of resistance (J. W.-I. Chan 2006; Pun 2005), both covert and incredibly overt. While in general accepting of the hegemonic discourse of 'rule by law', migrant workers in China's industrial heartland have become increasingly willing to take radical direct action if/when official channels fail to resolve their grievances. Non-payment of wages, working and living conditions, managerial abuse, workplace injuries, and low pay are the most common problems that can all incite outbursts of insurgency. Typically, migrants will attempt some sort of legal resolution to their grievances first, and if they manage to endure the exceedingly long process of mediation, arbitration and possibility litigation, they have a good chance of winning compensation. But many times, cases are deemed unfit for official intervention or workers cannot wait a year or more for resolution, and they will resort to direct action. Some frequent tactics include strikes, road blockages, sit-ins and threatening suicide. In recent years, there have been reports of more radical actions, including factory occupations, riots and murder (of bosses). Although there are exceptions, the state generally avoids harsh repression of migrant protest, and some concessions are often granted.

While worker protest in China has yet to present a serious threat to the stability of the regime, levels of insurgency are high and have been increasing dramatically in recent years. The number of officially reported 'mass incidents' grew rapidly throughout the early 2000s, eventually hitting 87,000 in 2005. While this was the final year that the government released such numbers, there were widespread reports that the number had jumped to an incredible 120,000 in 2008 (International Herald Tribune, 9 February 2009). The percentage of these mass incidents that are worker-related is unclear, but it surely accounts for a very significant share. As has been discussed, worker legal mobilization has been growing for more than 15 years, and it only accelerated with the passage of the Labour Contract Law and the outbreak of the financial crisis in 2008. Nationally, labour disputes increased by 98 per cent in 2008, and the increase continued into the first six months of 2009 with the three key provinces of Guangdong, Jiangsu and Zhejiang reporting increases of 41 per cent, 50 per cent, and an unbelievable 160 per cent, respectively (Caijing, 13 July 2009). What is crucial to note is how successful the state has 
been at shepherding aggrieved workers into the legal system, a process that is due in no small part to the enactment of the Labour Contract Law. Unfortunately, laws remain weakly enforced on the shop floor, and so grievances continue to increase in volume. The hugely overburdened labour courts cannot possibly keep up with the number of cases they receive, and so workers not infrequently resort to more radical action. While the growth of disorganized worker insurgency has forced the state to make some accommodations, these have mostly been to grant workers legislative concessions. But the state has not budged an inch on granting workers the right to organize their own unions.

\section{(a) Worker mobilization goes viral}

Although we have argued thus far that worker protest in China remains highly cellularized, there have been some relatively high-profile incidents that have led to copycat actions in other parts of the country. Successive strikes among steel and dock workers have been some of the most visible instances in which one successful action provokes worker insurgency in the same industry but in a different location. As yet, there is no evidence to suggest that these actions were consciously organized and co-ordinated, but rather that the strikes 'went viral' after appearing in media reports.

The origin of one such 'virus' came on 7 April 2007, when approximately 300 workers at Shenzhen's Yantian Port went on strike, crippling dock work and preventing 10,000 containers from being loaded or unloaded (Xin kuai bao, 9 April 2007). In addition to demanding better wages, the workers made the somewhat unusual demand to set up their own union, an indication of their desire to exercise greater control over their own workplace. Given the critical position of the port in international supply chains, the Shenzhen city government was quick to respond, with the labour bureau and trade union quickly coming to mediate. A resolution was quickly reached, whereby management agreed to raise all workers' wages by 3 per cent and to add an additional RMB 500/month on top. The Shenzhen Federation of Trade Unions decided to set up a union at the company, though it is unlikely that workers exercised much control over this process. Then, just a few weeks later, on the symbolically significant date of May 1, workers at Shenzhen's other port - the Chiwan Container Terminal - also went on strike (Associated Press, 2 May 2007). The several hundred workers who walked off the job demanded higher wages, at least four days of rest a month, a reduction in the severity of fines and that their employer follow relevant laws on overtime pay. After the outbreak of the strike, the story disappeared from the media, likely indicating the government's concerns about the discontent spreading yet further. 
This copycat-style of strike diffusion was repeated in another heavily publicized series of events in the summer of 2009. As part of a Central Government-promoted restructuring of China's steel industry, the private Beijing-based company Jianlong was to take a controlling share in the stateowned Tonghua Steel Company. During the lead-up to the restructuring, the general manger-to-be, Chen Guojun, called Tonghua's workers to a meeting to explain the future plans for the company. At the meeting, Chen told the employees that the company's workforce would be cut from the current 13,000 to 5,000 . Unsurprisingly, this lead to outbursts of anger among some of the workers, but Chen was unrepentant, yelling, 'If you do not kill me today and let me live, I promise you will not even get a bowl of vegetable soup to drink' (China Daily, 31 July 2009). Echoing the waves of radical worker protest during the widespread privatization of the 1990s and early 2000s (Cai 2002; Hurst 2004; Lee 2002), a reported 30,000 people protested in the streets, smashed police cars, and, most significantly, surrounded Chen and beat him to death. The story was widely covered in the media, with most reporters giving the workers a sympathetic treatment. On the Internet, an eruption of support for the workers and condemnation of the arrogance of Chen Guojun and the State-Owned Assets Supervision and Administration Commission added urgency to the situation. Plans for the restructuring were quickly scuttled and the workers walked away with a victory, albeit a bloody one.

Less than three weeks later, a very similar, though less spectacular, situation arose at the Linzhou Iron and Steel Company in Henan Province. In accordance with the Central Government's plan to restructure the steel industry, the Linzhou plant had been sold to the private steel company Fengbao the previous month. Unhappy with their treatment in the privatization, hundreds of workers began protesting on August 11. A few days later, 400 workers blocked a government official from the StateOwned Assets Supervision and Administration Commission inside the plant's offices. With the violence at Tonghua fresh in everyone's minds, riot police were deployed and the crowd eventually dispersed. However, the following day, the government announced that the privatization plan would be cancelled, handing yet another victory to militant steel workers.

Even though in these cases we see that a strike in one place can inspire a strike in another, the character of such protest is still fundamentally cellular in nature in the sense that the 'cells' are not combining to form 'tissues'. While such diffusion of strikes through a particular industry indicates an increase in worker consciousness and militancy, the actions that ignited the respective chain reactions were quite exceptional in their scale, visibility in the media and centrality to the functioning of the economy. Thus, while such inter-regional worker protest is a promising development, the spread of such a phenomenon will likely continue to be constrained by existing political conditions. 


\section{(b) The trade unions}

While sporadic and cellular protests by workers in both the state-owned and the private sector have not led to significantly improved labour conditions, they have certainly engendered a response from the state. Perhaps this is nowhere more evident than in the recent actions of the All China Federation of Trade Unions (ACFTU) and its subordinate unions. While the ACFTU has been quite effective in securing pro-labour legislation at the national, and sometimes provincial and municipal levels, enterprise-level unions remain incredibly weak and generally incapable of enforcing laws and contracts (F. Chen 2009; Ding et al. 2002; Lau 2001). Although municipal level unions have expanded their capacity to provide individuals with legal consultation (Chen 2004), the ACFTU remains categorically opposed to worker mobilization or to providing the working class with an autonomous base of organized collective power. While many recent legal reforms are welcome, unions in China remain exclusively reactive to collective action, and workers rarely recognize the legitimacy of the ACFTU.

First, it is necessary to explain something about the basic nature of trade unionism in China. The ACFTU claims a membership of 213 million, which would make it the largest national union federation in the world by a very large margin. As is well known, it is formally subordinate to the Chinese Communist Party, and all independent unionism is certain to be met by heavy-handed repression. Units at every level of the union hierarchy are subject to dual political control: first by the structurally horizontal Party organization, and second by the immediately superior trade union organization.

Chinese unions have been a frequent target of derision, with some asking 'is the ACFTU really a union?' (Taylor and Li 2007), while others have argued that it lives in an 'Alice in Wonderland dream world' (Metcalf and Li 2005). Chinese trade unionists unsurprisingly bristle at such criticisms, frequently claiming that foreigners have some 'misunderstandings' about the ACFTU. 4 We argue that there are in fact some misunderstandings, although for somewhat different reasons than a union official would. Against claims that Chinese unions are becoming corporatist (A. Chan 1993) or suffer from a 'double identity' (Chen 2003), we argue that Chinese unions think of themselves as, and behave like, government agencies (Lau 2003). When unions do engage in representation, it is important to note where agency is located in the representative relationship: it is a top-down process of 'we represent you,' (whether you like it or not) not a bottom-up 'we (workers) delegate authority to you.' Once this misunderstanding is clarified, much of the activity of the ACFTU and its subordinate unions is more easily interpretable.

Thus, the trade union's response to increasing worker insurgency has not been to try to direct this disorganized social movement towards a re-organization of power relations in society. Rather, it has 
been precisely what one would expect from an agency of the state: legislate and administrate. The Labour Law of 1995, Trade Union Law of 2001, and, more recently, the Labour Contract Law and Labour Mediation and Arbitration Law passed in 2007 have expanded legal protections for workers and increased the formal powers of the trade union. Although the ACFTU played a key role in advocating for these laws, nowhere was its presence more important than in the passage of the Labour Contract Law (the details of this law are discussed in more detail below). These legal reforms were in response to increased worker protest, and may not have been possible without the advocacy of the ACFTU. However, as forcefully argued by Feng Chen (2007), this increase in individual legal protections for workers is undermined by the lack of collective rights, namely freedom of association, for Chinese workers. As has been demonstrated in many cases were workers have unsuccessfully tried to establish their own organizations, the ACFTU retains a complete monopoly on trade unionism. For reasons too numerous to list here, the enterprise level trade unions within the ACFTU structure remain incredibly weak, and workers rarely identify with them (Howell 2003, 2008). In the few instances in which grassroots union chairs have tried to be more assertive in fighting for their membership's interests, they often face unchecked retaliation from employers. Higher levels of the trade union rarely intervene effectively to stop such anti-worker activities. The most blatant such case was in early 2009 , when an activist union chair was fired from a hotel that was owned by the Guangdong Federation of Trade Unions (Nanfang ribao, 23 April 2009). While the irony of a union activist being fired from a unionowned hotel incited significant public outcry, the basic pattern has appeared countless times throughout the country. With the union so fully subordinate to management at the point of production, there remain serious questions about the possibility of the individual rights enshrined in the law being enforced at all. Until workers have their own autonomous base of power, such a state of affairs is likely to continue.

\section{(c) Labour NGOs}

Starting in the mid-1990s, a number of labour-focused NGOs began to appear in Guangdong province's Pearl River Delta. This region of the country had been ground zero for the emergence of capitalist-style labour relations in the 1980s, and by the 1990s was populated by tens of millions of heavily exploited migrant workers. The terrible living and working conditions confronted by these workers have already been discussed. In part due to consumer movements in the Global North for 'sweat-free' products, and in part to the committed action of labour activists on the ground, several 
Chinese NGOs emerged which aimed to help workers defend their rights. We would like to emphasize two salient points about the activities of these NGOs: (i) they have, by and large, been active participants in the state's project of 'rule by law', and have sought to shepherd individual worker grievances into the systems of arbitration and the courts; and (ii) they have been subject to constant harassment and surveillance by the state, and as a result the scope of their activities remains quite limited.

Both the international and domestic political and institutional contexts are imprinted on the form and content of Chinese labour NGOs. What is particularly worth noting, however, is how successful the state has been in channelling international support for NGOs toward the goals of individualization and 'administrative-ization' of labour conflicts. As has been the case in many other developing countries, foundations and international organizations have had a profound influence on the development of the NGO sector (Bartley 2007; Luong and Weinthal 1999), one result of which has been that grievances as defined by Chinese workers themselves are often overlooked (Friedman 2009). In part because of the restrictive political environment in China, many foreign foundations (most of which hope to maintain good ties with the government) are committed to programs that promote 'rule of law.' Banned from membership-based funding, the result has been that most of the labour NGOs in China have adjusted to these requirements.

With both foreign funders and the Chinese state backing legalistic approaches to labour rights activism, most organizations are primarily engaged in legal advising and legal training (Yin and Yang 2009; Yue 2007). It is true that some NGOs have been somewhat more daring and attempted dormitory organizing or establishing worker committees (J. W.-I. Chan 2006), and there have been instances were they have provided workers with guidance, if not leadership, in more confrontational struggles with management. Some NGOs give workers training in organizing skills in order so that they can fight their own struggles in the workplaces. That being said, most labour NGO attention is focused on providing workers with afterthe fact advice on how to attempt to resolve grievances through the officially administered processes of mediation, arbitration and litigation. Since violation of the law is not just an occasional occurrence but an inherent tendency of the state's model of capital accumulation, labour grievances are endemic. And because workers do not posses any collective and durable means of preventing such violations at the point of production, NGOs have plenty of work on their hands. In addition to the typical non-profit NGOs, there is now a booming business of so-called 'citizen's agents,' or legal workers who, for a fee, try to help migrant workers win compensation for back-pay, workplaces injuries, etc. (Liaowang, 30 October 2007). While many activists are aware that legalistic approaches can be quite limiting, the political 
sensitivity of labour issues for the state, combined with foundation support for law-oriented programs, means that they are often left with little choice.

Even though most labour NGOs in China have been quite conservative and generally not engaged in any direct political activities, they have faced frequent harassment and repression from the state. A leaked internal report written by the Guangdong Communist Party Committee's Law and Politics Committee in January 2009 is proof of deep paranoia on the part of the local state with regards to the development of labour NGOs. The report focuses on 'citizen's agents' and NGOs, many of which are specifically named, and argues that they present 'a real impact and a potential threat to social stability in Guangdong province.'5 These groups are said to, 'intensify conflicts,' 'damage labour relations,' 'cause disorder in public management,' and, most seriously, 'harm state security.' The following excerpt from the section on state security is illustrative of these concerns:

Because at present 'professional citizen's agents' are not effectively under the control of the government, some foreign NGOs have grabbed the opportunity, and by using the advantage of deep financial resources have spent money to establish some 'rights protection' organizations that specifically focus on the disadvantaged group of migrant workers. These civil organizations receive financial support from foreign anti-Chinese forces, and use free legal representation as bait. They participate in some typical litigation cases, actively carry out human rights factory investigations, and collect negative information on our labour and legal issues. This is to provide gossip for foreign enemy forces to attack our labour system, legal system, human rights system, and to slander the image of our government. 6

That the report implies a direct connection between labour rights work and 'anti-Chinese' sentiment reveals something fundamental about the character of the post-Mao state. But the more relevant point is that despite any credible evidence of anti-state activity among NGOs, these organizations have very little space within which to operate, and therefore face incredible challenges in their day to day operations.

\section{New Challenges}

We have argued that commodification and casualization have been the two underlying processes shaping China's employment system and created numerous cellular worker protests that raise the spectre of social instability in the eyes of the Chinese government. Their response is to strengthen the 
force of contract through yet another labour legislation - the Labour Contract Law. The implementation of this law, which, among other things, requires employers to provide written contracts to employees and restricts the use of casual labour, coincides with the global financial crisis of 20082009. This does not bode well for the implementation of the Labour Contract Law. Yet with the overseas market for Chinese exports drastically curtailed, the Chinese government is compelled to pursue another round of economic restructuring. This time the emphasis is on creating domestic consumption demands, which means raising wage levels for the labouring masses, and replacing low-skilled and labour-intensive industries with technologically intensive and higher value-added enterprises. Finding a balance between these various imperatives becomes the new challenge for both the Chinese government and Chinese labour.

\section{(a) The Labour Contract Law}

The Labour Contract Law, which we have already touched on, was widely viewed as the most important change to China's labour relations legal framework since the 1995 Labour Law. This new law had aroused more public debate than perhaps any piece of legislation in the history of the PRC. After posting a draft version of the law in 2006 , the government received in excess of 190,000 public comments, many of them from regular workers. While the official trade unions and workers (in individual comments) tended to be supportive of the law, foreign and domestic capital publicly mobilized against it in a way which had not been done previously in China. Although the law was significantly watered down before enactment, it was widely hailed as a victory for workers. While we do not debate that the law may have positive material consequences for certain segments of workers, the promulgation of the law is yet another strong indication of the state's attempt to 'rule by law' and to cellularize labour conflict. Given this set of political circumstances, there is little reason to believe that the new law will adequately address the deep power asymmetry at the point of production.

At the most general level, the Labour Contract Law was viewed by the authorities as a means by which to formalize labour relations as part of a broader attempt to reduce social conflict and address growing economic inequality. One of the most important features of the new law are the provisions relating to 'non-fixed term' contracts, which make it more difficult to dismiss employees (J. W.-I. Chan 2009; Wang et al. 2009). According to the law, workers are entitled to demand a non-fixed term contract after signing two successive fixed-term contracts or after being employed for 10 years by the same employer. The law also includes an expanded role for the trade union in negotiating collective contracts, the determination of workplace rules and layoffs. Finally, the law requires enhanced 
severance payments in the event of layoffs, something that is particularly important in a country with a very weak system of unemployment insurance (Cooney et al. 2007).

When the draft version of this law was released to the public, employers took a very strong oppositional stance. Domestic and international representatives of capital, including the EU Chamber of Commerce and American Chamber of Commerce, heavily lobbied the government to express their opposition to the law. Some organizations, most notably the American Chamber of Commerce Shanghai, publicly threatened the government with capital flight if the law was passed. The business community was racked with fear, with some opining that the Labour Contract Law meant that China was limiting 'free enterprise' (The Sunday Times, 21 October 2007). And yet despite this outpouring of protest, the central government moved ahead with the law as the National People's Congress approved it in June 2007. The new law took effect from 1 January 2008.

While the draft law was passed, employer activism bore significant fruits. In March of 2008, a vice-minister of labour and social security spoke publicly to allay the fears of employers saying, '[nonfixed term contracts are] by no means an iron rice bowl. It will not lead to rigidity in the labour market' (China Daily, 10March 2008). And by many accounts, he was right: the final version of the law increased managerial autonomy and significantly weakened the role of the trade union in determining workplace rules and layoff procedures. Whereas before the union needed to approve such actions, the final version of the law called only for the union to be 'consulted,' thereby giving the green light to employers to act unilaterally. Additionally, the 'implementation rules' for the Labour Contract Law further delineated 14 instances in which workers with non-fixed term contracts could be dismissed. These include the enterprise encountering 'serious difficulty in production', 'inability to come to an agreement in negotiations' and 'large changes in objective economic conditions,' among others. It is unclear how precisely it is to be adjudicated whether these conditions pertain or not, nor is there any indication as to what happens if the union is not consulted during contract negotiations or layoffs (S. Chen 2009). These sorts of 'strategic ambiguities' (Ngok 2008) allow for flexibility in local application and also suggest wide variation in actual implementation.

It is still too early to render a final analysis of the effects of the Labour Contract Law on labour relations in China. It does appear that the intense public debate around the law caused more workers to take notice, one result of which has been many more workers filing complaints with the labour bureau. In particular, there appear to be many cases of workers filing against employers for failing to provide them with a contract, something that is heavily punishable under the new law. The huge increase in official labour disputes in 2008 can be attributed as much to the implementation of the Labour Contract 
Law as to the financial crisis, as disputes were on the rise even in the first half of the year. There are also signs that the law has been more useful to employees with other cultural or social resources at their disposal (Cooney et al. 2007), and who occupy a relatively strong position in the labour market. Successful pushback by white-collar employees at Wal-Mart and tech giant Huawei are clear examples of such a phenomenon. While it is not clear that the laws are being enforced more strictly than before, it does appear that more workers now have written contracts, and in this sense a first step toward formalization has been achieved.

It is precisely when we come to this issue of providing workers with contracts we can see that the Labour Contract Law is at base a further attempt to guide individual worker grievances into the official system of labour mediation. True, there are provisions in the law for collective bargaining and a marginally enhanced role for the union in determining work rules and consulting around layoffs. But in the absence of a union that can constitute its membership as a collective force (or that has any substantive connections to workers whatsoever), such provisions are rendered insignificant. Why then is this law a further manifestation of the state's attempts to 'rule by law' and to cellularize labour conflict? Because the strongest censure in the law is reserved for employers who do not provide their workers with contracts (and because this feature has been highly publicized), more and more workers now have access to such contracts. This is absolutely crucial for the state, because without a written contract, the labour bureau cannot process a grievance. The provision of contracts to workers is thus necessary in order for the state to be able to absorb conflict and (attempt) to keep it out of the workplace and the streets. And yet the severely overburdened labour bureaus are frequently unable to efficiently and fairly resolve such conflicts, the consequence of which is that workers still must resort to direct action. Such problems became painfully apparent when the global financial crisis hit in late 2008.

\section{(b) The response to the global economic crisis}

As the US housing crisis morphed into a financial and then a full-blown economic crisis in the fall of 2008, China's export-dependent economy suffered its first major shock in years. In rather short order, this disruption led to massive unemployment, engendering widespread conflicts, protests and riots, and forcing an estimated 20 million migrant workers to return to the countryside (The New York Times, 2 February 2009). The crisis has been yet another moment in which we can witness the increasing strength of the state-capital alliance in China, as the government's response was, by and large, directed towards assisting employers in the hopes of boosting employment, rather than directly providing workers with jobs. 
Although the effects of the economic crisis have been uneven, all regions with an exportoriented economy were severely impacted. During the first half of 2009, the value of China' exports declined by 21.9 per cent over the previous year (Bloomberg News, 31 July 2009). No region was more adversely affected than the heavily export dependent Pearl River Delta. In mid-December, an official from the Guangdong government revealed that 15,661 small and medium enterprises had closed or gone bankrupt during the year, but awkwardly maintained that, "there has not been a "wave of closings" (Yangcheng wanbao, 17 December 2008) In the manufacturing town of Dongguan, the government reported that 117 bosses skipped town without paying workers their owed wages. For the factories that did not shut down, their orders were dramatically reduced, which resulted in massive layoffs.

While millions of workers simply went home for Chinese New Year, many of them without receiving their due wages, there were thousands of disputes, official complaints, strikes and riots. As has already been mentioned, disputes grew particularly rapidly in the export-oriented provinces of Jiangsu, Zhejiang and Guangdong. There were reports of militant direct action with 1,000 workers at a Shanghai electronics plant staging a massive sit-in to protest six months of unpaid overtime wages and benefits (AFP, 9 December 2009), and an occupation of a textile mill by 6,000 workers in the Northern city of Linfen (The Sunday Times, 1 February 2009). The unrest was not restricted to the manufacturing sector, as taxi drivers staged a nearly unprecedented nationwide wave of strikes, with drivers walking off the job in Chongqing, Guangzhou, Shantou, Foshan, Sanya, Xiamen, Jingzhou, Suizhou, Zhouzhi, Nanyang, Anling, Dali and Yongdeng. In Dongguan, hundreds of workers from a toy factory rampaged through their workplace, eventually battling police, smashing and overturning a police vehicle (Guangzhou ribao, 26 November 2008). Finally, in at least a few cases, legal violations pertaining to layoffs and severance pay resulted in workers murdering their managers (Nanfang dushi bao, 31 March 2009).

What then was the response of the state? To a certain extent, the interests of the state and the working class began to coincide in some small way as the crisis intensified. Both the central government and local governments feared that increased unemployment would affect social stability, and so they began to persuade employers to avoid layoffs, in some cases going to far as to ban the practice in stateowned enterprises without explicit government approval (Xinjing bao, 15 January 2009; Bandao chenbao, 14 January 2009). Local governments managed to cajole a handful of employers to publicly promise to not engage in layoffs, with the hope that other companies would follow suit. And many local governments took steps to ensure that employers would not disappear without paying workers their owed wages. 
On the whole, though, the crisis revealed the extent to which the state has accepted the interests of capital as hegemonic.7 The central government announced that it would allow localities to freeze increases in the minimum wage, and that they could reduce employer contributions to their employees' social insurance (Wall Street Journal, 16 January 2009), something many municipalities took advantage of. Of even greater concern were widespread reports that government officials were overlooking legal violations by employers in the hopes of keeping investors happy. In Shandong, there was a report of a government official telling a foreign investor not to 'worry so much' about the Labour Contract Law (China Law Blog, January 2009), and in Guangdong, legal enforcers were told that investigations against managers suspected of breaking the law could be postponed (Guangzhou ribao, 1 January 2009). The Guangdong government argued that, 'this method is to ensure the normal functioning of the enterprise, and certainly is not to provide suspects with protection' (Xin kuai bao, 1 January 2009).

Once again, the working class' inability to exercise co-ordinated collective power meant that worker interests were overlooked and violated. With resolution of labour arbitration cases frequently taking one or even two years, the legal system proved incapable of delivering justice to workers when they needed it most. Additionally, in the absence of a strong lobby from organized labour, the response of the state was, by and large, directed toward assisting employers. Deprived of organized political power, working class insurgency erupted throughout the country, in an (frequently vain) attempt to redress deep grievances. The basic pattern of legal violations by capital, failure to resolve conflicts through legal mediation, followed by worker direct action, has been developing throughout the period of marketization; the economic crisis merely increased the frequency and intensity of such a dynamic.

\section{Conclusion}

The analysis provided here has focused on the shifting structure of employment, modes of labour organization and resistance, and recent major events in an attempt to summarize the massive changes that Chinese workers have experienced in the past 30 years. Employment relations have been characterized by a shift from a social to a legal contract, a process that implies the commodification of labour power. Casualization has been brought about by an increasing percentage of employment opportunities appearing in the private sector, while state-owned firms have been reformed to more closely resemble their privately owned competitors. Labour conditions for Chinese workers vary greatly, but employees are frequently subjected to long hours, low pay, summary firings, and non-payment of 
wages and insurance. Additionally, the increased presence of temporary and 'dispatch' workers in the economy further dissolves possible class cohesion and increases precarity in workers' lives.

Workers have not been passive in the face of this assault on their interests. Both workers in the state-owned and private sector have been protesting with great frequency, though the origins and dynamics of such insurgency vary. While the majority of worker activism remains cellular and generally not explicitly political in character, there have been instances in which worker insurgency in a particular sector has spread to multiple workplaces. However, the state is still categorically opposed to independent worker-based organization, as is evidenced by the constant harassment, surveillance and repression directed at the tiny and generally conservative NGO sector. Meanwhile, the official trade union remains tied to the accumulation-oriented state apparatus, and is unwilling to be antagonistic to capital. Perhaps the most important achievement of the ACFTU in the past decade has been the passage of the Labour Contract Law, a piece of legislation that theoretically increases protections for workers. However, revisions to the law significantly reduced legal protection against arbitrary firings, and there are widespread reports of lax enforcement of the law. Finally, when the export economy collapsed in late 2008 , the degree to which the state had accepted the interests of capital as hegemonic became more starkly revealed.

These dynamics reveal important features of reconfigured class and labour politics in reform-era China. Marketization has generated a huge increase in worker insurgency that, as of today, has yet to coalesce into an organized social movement. The response of the state has been to try to legislate conflict out of existence, the result of which has been an individualization of what are necessarily collective problems. As officially mediated labour conflicts continue to grow rapidly, a deep power asymmetry at the point of production - something that emboldens employers to routinely flout the law - emerges unscathed. The Party state has created a rough approximation of the neoliberal ideal whereby a disorganized mass of individuals is forced to confront the hegemonic power of state and capital as individuals. Even laws with a high degree of central government backing frequently go unenforced as local officials' interests are closely aligned with those of capital. Since workers have a stronger incentive to have the laws enforced than do employers, the one path out of this impasse would be to allow workers to exercise collective and independent power. 'Empowering' workers with individualized legal rights cannot address the fundamental imbalance. However, granting workers the collective right of freedom of association is one measure that the central government appears constitutionally opposed to. The consequence is that higher levels of the state are in a bind, where they are unwilling to do the thing that would allow for their laws to be fully implemented. 
One implication of this is that the state's current attempts to shift from an export-oriented economy to one that is based on domestic consumption may be confounded by existing dynamics of class and state power. With speculation emerging that the government may try to mandate higher wages in order to decrease the current accounts surplus and to spark domestic consumption (Bloomberg, 9 February 2010), the enforceability of wage and labour laws are of central importance. However, none of the series of recent laws that are supposed to strengthen workers' legal rights, and the power of the official trade unions have seemingly done anything to reduce labour conflict or increase adherence to the law. Thus, it appears as if the commodification, casualization, and legal individualization that has been foisted on the working class may have negative consequences not just for workers who are continually subjected to reconfigured relations of class domination, but also on the realization of the central state's own goals.

Final version accepted on 27 April 2010.

\section{Notes}

1. Eli Friedman studied two elevator and escalator factories in Guangzhou as part of his dissertation research.

2. Laodong Zhengyi Chuli Yu Yanjiu (Labour Disputes: Handling and Research) 1995, 1996, 1997, various articles; see also Chinese Labour and Social Security Yearbook, from 1995 to 2001 (Beijing: Zhongguo Laodong he Shehuibaozhang Chubanshi).

3. China Labour Bulletin, 12 January 2009. http://www.clb.org.hk/en/node/100366. Accessed 10 April 2009.

4. It should be noted that such critiques are not limited to foreigners; however, given the lack of autonomy of the academic field in China, such commentary is usually much more muted when published domestically.

5. 1 January 2009. 'guanyu guangdongsheng "zhiye gongmin dailiren" wenti de diaocha baogao' [Research report on the problem of 'professional citizen's agents' in Guangdong Province]. Zhonggong Guangdong shengwei zhengfa weiyuanhui.

6. See note 5 .

7. Here we use 'hegemonic' in the specifically Gramscian meaning, in which specific class interests appear as general interests. 


\section{References}

Bartley, T. (2007). 'How foundations shape social movements: the construction of an organizational field and the rise of forest certification'. Social Problems, 54 (3): 229-55.

Cai, Y. (2002). 'The resistance of Chinese laid-off workers in the reform period'. The China Quarterly, 170: $327-44$.

Chan, A. (1993). 'Revolution or corporatism?Workers and trade unions in post-Mao China'. The Australian Journal of Chinese Affairs, 29: 31-61.

- - (2001). China's Workers Under Assault: The Exploitation of Labor in a Globalizing Economy. Armonk, NY: M.E. Sharpe.

Chan, J. W.-I. (2006). 'Chinese women workers organize in the export zone'. New Labor Forum, 15 (1): 19-27.

- (2009). 'Meaningful progress or illusory reform? Analyzing China's Labor Contract Law'. New Labor Forum, $18(2):$ 43-51.

Chen, F. (2000). 'Subsistence crises, managerial corruption and labour protests in China'. The China Journal, 44: 41-63.

- (2003). 'Between the state and labour: the conflict of Chinese trade unions' double identity in market reform'. The China Quarterly, 176: 1006-28.

- (2004). 'Legal mobilization by trade unions: the case of Shanghai'. The China Journal, 52: 27-45.

- - (2007). 'Individual rights and collective rights: labor's predicament in China'. Communist and PostCommunist Studies, 40: 59-79.

- (2009). 'Union power in China: source, operation, and constraints'. Modern China, 35: 662-89.

Chen, S. (2009). 'Dui “laodong hetong fa”' shishi guocheng zhong ruogan wenti de sikao' [On some issues in the implementation of the Labor Contract Law]. Hunan sheng gonghui ganbu xuexiao, 23 (3): $30-2$.

Coke Concerned Student Group (2009). Hangzhou kekoukele zhuangpingchang diaocha baogao [Investigative Report on Hangzhou Coca-Cola Bottling Plant]. Coke Concerned Student Group.

Cooney, S., Biddulph, S., Li, K. and Zhu, Y. (2007). 'China's New Labor Contract Law: responding to the growing complexity of labour relations in the PRC'. University of New South Wales Law Journal, 30: 786-801.

Ding, D. Z., Goodall, K. and Warner, M. (2002). 'The impact of economic reform on the role of trade unions in Chinese enterprises'. International Journal of Human Resource Management, 13 (3): 431-49. 
Eastern Center for Legal Culture (ed.) (2008). The Dispatching of Services. Shanghai: Renmin Publishing House (in Chinese).

Evans, P. and Staveteig, S. (2009). 'The changing structure of employment in contemporary China'. In D.

Davis and F. Wang (eds.), Creating Wealth and Poverty in Postsocialist China. Stanford, CA:

Stanford University Press, pp. 69-84.

Friedman, E. (2009). 'External pressure and local mobilization: transnational activism and the emergence of the Chinese labor movement'. Mobilization: An International Journal, 14 (2): 199-218.

Gallagher, M. (2004). 'Time is money, efficiency is life: the transformation of labor relations in China'. Studies in Comparative International Development, 39 (2):11-44.

- - (2005). Contagious Capitalism: Globalization and the Politics of Labor in China. Princeton, NJ:

Princeton University Press.

Howell, J. (2003). 'Trade unionism in China: sinking or swimming?' Journal of Communist Studies and Transition Politics, 19 (1): 102-22.

- (2008). 'All-China Federation of Trade Unions beyond reform? The slow march of direct elections'. China Quarterly, 196: 845-63.

Hurst, W. (2004). 'Understanding contentious collective action by Chinese laid-off workers: the importance of regional political economy'. Studies in Comparative International Development, 39 (2): 94-120.

- - (2009). The Chinese Worker after Socialism. Cambridge: Cambridge University Press.

Lau, R. W. K. (2001). 'Socio-political control in urban China: changes and crisis'. British Journal of Sociology, 52 (4): 605-20.

- (2003). 'The habitus and "logic of practice" of China's trade unionists'. Issues \& Studies, 39 (3): 75103.

Lee, C. K. (2000). 'The "revenge of history": collective memories and labor protests in north-eastern China'. Ethnography, 1 (2): 217-37.

- (2002). 'From the specter of Mao to the spirit of the law: labor insurgency in China'. Theory and Society, 31: 189-228.

- - (2007). Against the Law: Labour Protests in China's Rustbelt and Sunbelt. Berkeley, CA: University of California Press.

- - (2010). 'Pathways of labour insurgency'. In E. Perry and M. Selden (eds.),

Li, H. (2005). 'Fazhan yu yinyou: woguo laowu paiqian xianzhuang zhi wojian' [Development and hidden 
dangers: my views on the current conditions for Chinese dispatch labor]. Shengli youtian dangxiao xuebao, 18 (5): 46-9.

Liu, T., Zhong, M. and Xing, J. (2005). 'Industrial accidents: challenges for China's economic and social development'. Safety Science, 43: 503-22.

Liu, Y. (2009). 'Cong tonggongtongchou kan paiqiangong laodong pingdeng wenti' [Looking at the problem of equality for dispatch labor from the perspective of equal pay for equal work]. Hunan xingzheng xueyuan xuebao, 2 (56): 49-51.

Luong, P. J. and Weinthal, E. (1999). 'The NGO paradox: democratic goals and non-democratic outcomes in Kazakhstan'. Europe-Asia Studies, 51 (7): 1267-84.

Metcalf, D. and Li, J. (2005). Chinese Unions: Nugatory or Transforming?-An Alice Analysis. London: Centre for Economic Performance.

Ngok, K. (2008). 'The changes of Chinese labor policy and labor legislation in the context of market transition'. International Labor and Working-Class History, 73:45-64.

Park, A. and Cai, F. (2007). 'The Informalization of the Chinese Labor Market'. Unpublished manuscript.

Pun, N. (2005). Made in China: Women Factory Workers in a Global Workplace. Durham, NC: Duke University Press.

Qiao, J. (2009). 'The New Labour Contract Law and labour conditions in 2008'. In Y.

Xin, X. Y. Lu and P. L. Li (eds.), Society of China: Analysis and Forecast. Beijing: Social Science Academic Press (China), pp. 312-27 [in Chinese].

State Council Research Office Team (2006). China's Migrant Workers Survey Report. Beijing: China Yanshi Publishing House (in Chinese).

Sun, F. (2009). 'Laowu paiqian yonggong fangshi xia laozi sanfang xingwei de boyi fenxi' [An analysis of tripartite labor-capital activities under the system of dispatch labor]. Fazhi yu shehui, 243.

Taylor, B. and Li, Q. (2007). 'Is the ACFTU a union and does it matter?' Journal of Industrial Relations, 49 (5): 701-15.

Walder, A. (1986). Communist Neo-Traditionalism: Work and Authority in Chinese Industry. Berkeley: University of California Press.

Wang, H., Appelbaum, R. P., Degiuli, F. and Lichtenstein, N. (2009). 'China's New Labour Contract Law: is China moving towards increased power for workers?' Third World Quarterly, 30 (3): 485-501.

Wright, T. (2004). 'The political economy of coal mine disasters in China: your rice bowl or your life'. The China Quarterly, 179: 629-46.

Yin, G. and Yang, M. (2009). 'Shenzhen laogong yu Shenzhen laogong feizhengfu zuzhi' [Shenzhen's labor 
and Shenzhen's labor NGOs]. Chongqing gongxueyuan xuebao (shehui kexue), 23 (6): 112-15.

Yue, J. (2007). 'Feizhengfu zuzhi yu nongmingong quanyi de weihu - yi panyu dagongzu wenshu chuli fuwubu wei ge'an' [NGO and the protection of peasant workers: a case study of Panyu Service Department for Peasant Workers]. Zhongshan daxue xuebao, 47 (3): 80-5.

Zhang, L. (2008). 'Lean production and labor controls in the Chinese automobile industry in an age of globalization'. International Labor and Working-Class History, 73 (1): 1-21.

Zhang, O. (2009). 'Ladong hetongfa banbu beijing xia dui laowu paiqiangong daiyu wenti de yanjiu yu sikao'. Zhiye jishu, (106): 78. 